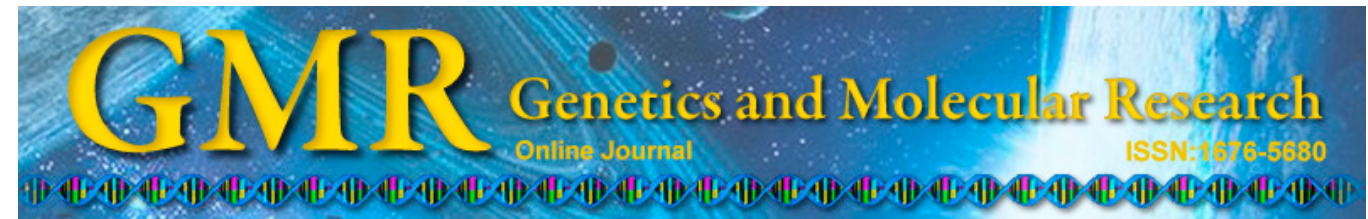

\title{
Molecular characterization, tissue expression, and polymorphism analysis of liver-type fatty acid binding protein in Landes geese
}

\author{
Z. Song*, D. Shao*, X.X. Sun, J.W. Niu and D.Q. Gong \\ College of Animal Science and Technology, Yangzhou University, Yangzhou, \\ Jiangsu Province, China \\ *These authors contributed equally to this study. \\ Corresponding author: D.Q. Gong \\ E-mail: yzgong@163.com
}

Genet. Mol. Res. 14 (1): 389-399 (2015)

Received January 8, 2014

Accepted August 27, 2014

Published January 23, 2015

DOI http://dx.doi.org/10.4238/2015.January.23.12

\begin{abstract}
Liver weight is an important economic trait in the fatty goose liver industry. Liver-type fatty acid binding protein (L-FABP) is involved in the formation and metabolism of fatty acids. Thus, we hypothesized that sequence polymorphisms in $L-F A B P$ were associated with fatty liver weight in goose. We first isolated, sequenced, and characterized the goose $L-F A B P$ gene, which had not been previously reported. The goose $L-F A B P$ gene was $2490 \mathrm{bp}$ and included 4 exons coding for a 126-amino acid protein. Analysis of expression levels of the goose $L-F A B P$ gene in different tissues showed that the expression level in the liver tissue was higher than in other tissues, and was significantly higher in the liver tissue of overfed geese than in control geese. Moreover, a single nucleotide polymorphism located at $774 \mathrm{bp}$ in the gene was identified in a Landes goose population. To test whether this single nucleotide polymorphism was associated with fatty liver production, liver weight and the ratio of liver to carcass weights were determined for the 3 genotypes with this single nucleotide polymorphism (TT, TG, $\mathrm{GG})$ in overfed Landes geese. Our data indicate that individuals with
\end{abstract}


the GG genotype had higher values for the variables measured than those with the other 2 genotypes, suggesting that $L-F A B P$ can be a selection marker for the trait of fatty liver production in goose.

Key words: $L-F A B P$ gene; Fatty liver; Landes geese; Polymorphism; Tissue expression

\section{INTRODUCTION}

Fatty acid binding proteins (FABPs) are small intracellular proteins present in most types of animal cells and contain 126-134 amino acids. They are primarily involved in fatty acid transport from the plasma membrane to sites of $\beta$-oxidation and synthesis of triacylglycerol and phospholipids (Richieri et al., 1996). Furthermore, FABPs have strong long-chain fatty acid binding activity and play an important role in the oxidation, esterification, and metabolism of fatty acids (Wang et al., 2006). Liver FABP (L-FABP) is the major soluble protein that binds very long-chain n-3 polyunsaturated fatty acids in hepatocytes (Petrescu et al., 2013). As the levels of fatty acid increase, the expression levels of L-FABP also significantly increase in most cells (Zhou et al., 2010). Among the FABPs in mammals, L-FABP is the most broadly distributed mammalian FABP and is very highly expressed in tissues and most active when unesterified long-chain fatty acid (LCFA) metabolism is low (Atshaves et al., 2010). The biological function and metabolic mechanism of the $L-F A B P$ gene has been well-studied in mammals, but not in goose, possibly because of the unusual fatty acid metabolism system in geese. Because of its structure and functions, L-FABP is more efficient than other types of FABPs in mammals; each L-FABP molecule in goose binds 2 fatty acids, whereas other FABPs can bind only 1 . A previous study showed that the fatty acid binding ability and the amount of triacylglycerol in $L-F A B P$ gene knock-out mice, as well as the absorption and diffusion of fatty acids, were decreased (Martin et al., 2003). Liver weight in $L$-FABP gene knockout mice was significantly increased and these mice exhibited macroscopic steatosis. The lack of $L-F A B P$ not only modified intestinal fatty acid composition, but also affected adenoma formation in ApcMin/+ mice (Newberry et al., 2003; Seneshaw et al., 2005; Dharmarajan et al., 2013). Recent studies indicated that L-FABP can be used as a novel marker for diet-induced nonalcoholic fatty liver disease and organ damage caused by specific types of cancer (Relija et al., 2010; Chen et al., 2013).

In birds, Wang et al. (2006) showed that the expression of the chicken $L$-FABP gene was restricted to the liver and small intestine. In the same study, $L-F A B P$ gene polymorphisms were associated with abdominal fat weight and percentage of abdominal fat, and the $L-F A B P$ gene may be a candidate locus or linked to a major gene that affects fatness traits in chicken. The expression levels of the $L-F A B P$ gene in liver of overfed Landes geese are significantly up-regulated compared with those of control geese using the method of differential display reverse transcription-polymerase chain reaction (PCR) and semi-quantitative reverse transcription-PCR $(\mathrm{Xu}, 2008)$. The high expression level of the $L-F A B P$ gene in liver of overfed geese expedited the transport of long-chain fatty acids to sites of synthesis of triacylglycerol and phospholipids and promoted synthesis of fatty acids in liver. Changes in the expression levels of the $L-F A B P$ gene suggested that this protein can be used as a marker of hepatic lipidosis. 
In this study, we first cloned and analyzed the goose $L-F A B P$ gene and detected its expression levels and association with fatty liver weight to investigate the function of the $L-F A B P$ gene in the formation of goose fatty liver. The role of L-FABP in the formation and metabolism of fatty acids has been well-studied in mammals; thus, we examined the physicochemical properties and physiological functions of L-FABP in Landes geese. This information will be useful for future studies on L-FABP and its relationships with obesity.

\section{MATERIAL AND METHODS}

\section{Experimental animals and isolation of total RNA}

A total of 6 healthy 70-day-old Landes geese were provided by the Wu Wang Farm (Chuzhou, China) and used to detect $L-F A B P$ gene mRNA expression levels. All geese were randomly divided into an overfeeding group $(\mathrm{N}=3)$ and a control group $(\mathrm{N}=3)$. In the overfeeding group, 3 geese were slaughtered at 90 days of age after 20 days overfeeding with a carbohydrate diet consisting of boiled maize (boiled maize mixed with $1 \%$ plant oil and 0.8 $1 \%$ salt). In the control group, 3 geese were fed maize ad libitum and slaughtered at 90 days of age. Overfed geese $(\mathrm{N}=82)$ were subjected to polymorphism analysis. All geese were kept in cages with a conventional and appropriate humane overfeeding approach and feed management (Zhang et al., 2013). Tissues were taken from slaughtered geese and immediately frozen in liquid nitrogen and then stored at $-80^{\circ} \mathrm{C}$ until use. Total RNA was isolated by TRIzol (Tiangen Biotech Co., Ltd., Beijing, China) from heart, liver, fat tissue, spleen, lung, kidney, pectoral muscle, and crureus muscle. Reverse transcription of total RNA was carried out according to the Prime Script ${ }^{\mathrm{TM}} \mathrm{RT}$ reagent kit Perfect Real-Time kit (Takara Biotechnology (Dalian) Co., Ltd., Shiga, Japan). This project was approved by the Yangzhou University Animal Ethics Committee.

\section{Cloning and sequencing}

The cDNA was amplified by PCR. Referring to the anatine $L-F A B P$ gene cDNA sequence (GenBank accession No. HQ640427.1), primers were designed and synthesized: forward (L-FABPF): 5'-ATGGCATTCAGTGGAACCTGGCAG-3' and reverse (L-FABPR): 5'-GCGATTAAACTCTCTTGCTTCTTCTGACAA-3'. The 20- $\mu \mathrm{L}$ PCR product was composed of $1 \mu \mathrm{L}$ cDNA, $2 \mu \mathrm{L}$ 10X LA PCR Buffer II ( $\mathrm{Mg}^{2+}$ Plus), $2 \mu \mathrm{L}$ dNTPs, $1 \mu \mathrm{L}$ of each primer, $0.2 \mu \mathrm{L}$ Takara LA Taq enzyme, and $12.2 \mu \mathrm{L} \mathrm{ddH}_{2} \mathrm{O}$. PCR was performed under the following conditions: cDNA was denatured at $95^{\circ} \mathrm{C}$ for $5 \mathrm{~min}$, followed by 35 cycles of amplification $\left(95^{\circ} \mathrm{C}\right.$ for $30 \mathrm{~s}, 58^{\circ} \mathrm{C}$ for $30 \mathrm{~s}$ and $72^{\circ} \mathrm{C}$ for $\left.2 \mathrm{~min}\right)$, a final extension of 10 min at $72^{\circ} \mathrm{C}$ and saved at $4{ }^{\circ} \mathrm{C}$. PCR products were sequenced by Sangon Biotech Co., Ltd., Shanghai, China).

\section{Tissue expression analysis}

The expression levels of the $L-F A B P$ gene in different tissues were measured using the SYBR-Green method. A SYBR Premix Ex Taq ${ }^{\mathrm{TM}}$ (Perfect Real Time) kit was used for quantitative PCR and variations in the amount of starting material were normalized to 
glyceraldehyde-3-phosphate dehydrogenase gene (primers, forward: 5'-GCCATCAATGAT CCCTTCAT-3', reverse: 5'-CTGGGGTCACGCTCCTG-3'). The 20- $\mu \mathrm{L}$ PCR was composed of $10 \mu \mathrm{L} 2 \mathrm{X}$ UltraSYBR Mixture, $0.4 \mu \mathrm{L}$ of each primer, $2 \mu \mathrm{L} \mathrm{cDNA}$, and $7.2 \mu \mathrm{L} \mathrm{ddH}_{2} \mathrm{O}$. The PCR profile was performed under the following conditions: cDNA was denatured at $95^{\circ} \mathrm{C}$ for $10 \mathrm{~min}$, followed by 40 cycles of $95^{\circ} \mathrm{C}$ for $15 \mathrm{~s}$ and $60^{\circ} \mathrm{C}$ for $1 \mathrm{~min}$; all samples were tested 3 times. Primers were designed for $L-F A B P$, including forward: 5'-CAGAAGAACTTATCAAA GTCG-3' and reverse: 5'-CGTCCATAGTAGTAATATCAGC-3'. The results of quantitative reverse transcription-PCR were calculated using the $2^{-\mathrm{ACt}}$ method and relative quantitative analysis was performed.

\section{Gene polymorphism identification and analysis}

According to the sequence of the goose $L-F A B P$ gene obtained in this study, 8 pairs of primers (Table 1) were designed using Oligo7.0 and synthetized by Sangon Biotech to detect polymorphic sites in $L-F A B P$. The $20-\mu \mathrm{L}$ PCR product was composed of $1 \mu \mathrm{L}$ DNA (approximately $100 \mathrm{ng}$ ), $2 \mu \mathrm{L} \mathrm{10X}$ buffer, $0.8 \mu \mathrm{L}$ dNTPs $(10 \mathrm{mM}), 1.8 \mu \mathrm{L} \mathrm{Mg}^{2+}(25 \mathrm{mM}), 1$ $\mu \mathrm{L}$ of each primer, $0.2 \mu \mathrm{L} \mathrm{Taq}$ enzyme $(5 \mathrm{U} / \mu \mathrm{L})$, and $12.2 \mu \mathrm{L} \mathrm{ddH}_{2} \mathrm{O}$. The PCR profile was performed under the following conditions: DNA was denatured at $95^{\circ} \mathrm{C}$ for $10 \mathrm{~min}$, followed by 32 cycles at $95^{\circ} \mathrm{C}$ for $30 \mathrm{~s}$, annealing at different temperatures for $30 \mathrm{~s}$, and $72^{\circ} \mathrm{C}$ for $30 \mathrm{~s}$, a final extension for $10 \mathrm{~min}$ at $72^{\circ} \mathrm{C}$ and saved at $4{ }^{\circ} \mathrm{C}$. PCR products were sequenced to identify polymorphisms in the $L-F A B P$ gene.

Table 1. Primer sequences and polymorphisms in the goose $L-F A B P$ gene.

\begin{tabular}{llccc}
\hline Primer ID & Sequence (5'-3') & Amplicon (bp) & Location & Nucleotide polymorphism \\
\hline L-F1 & ATGGCATTCAGTGGAACCT & 267 & Exon 1 & None \\
L-R1 & GACTCGTGTTAAGATTGCTTC & 320 & Exon 2 & None \\
L-F2 & GTATCAATGCACTATGTCATAACAG & 332 & Exon 3 & None \\
L-R2 & AACAGGTTTTACTCATGCACA & 204 & Exon 4 & None \\
L-F3 & AAAACTCTTATTAAAATACGGTGA & 138 & Intron 1 & to G \\
L-R3 & TTTTAAAATGTATTGAGCCCAT & 208 & Intron 1 & None \\
L-F4 & TGTAACTCCTACTAGGCTCTG & 162 & Intron 2 & None \\
L-R4 & TTAAACTCTCTTGCTTCTTCTGAC & 216 & Intron 2 & None \\
\hline
\end{tabular}

\section{Bioinformatic analysis}

The sequence of exons and introns in the $L-F A B P$ gene was analyzed by sequence alignment using the DNAMAN software. The amino acid sequences of the $L-F A B P$ gene were compared with those of other organisms and a phylogenetic tree was constructed using the MEGA5.05 software. Protein physical and chemical property analysis and hydrophobicity/ hydrophilicity cluster analysis were performed using ProtParam and ProtScale of ExPASy (http://www.expasy.org), respectively.

The genotype frequency, allele frequency, heterozygosity, and colony polymorphism information content of the Landes of goose $L-F A B P$ gene were calculated using the PopGen software. Colony Hardy-Weinberg equilibrium was detected using the chi-square test. The association between single nucleotide polymorphisms and fatty liver traits was analyzed by oneway analysis of variance analysis using the SPSS17.0 software (SPSS, Inc., Chicago, IL, USA). 


\section{RESULTS}

\section{Cloning and sequencing of the goose $L-F A B P$ gene}

The goose $L-F A B P$ gene complete coding sequences have a length of $2490 \mathrm{bp}$, consisting of 4 exons and 3 introns (Figure 1) and encoding a peptide of 126 amino acids (Figure 2).

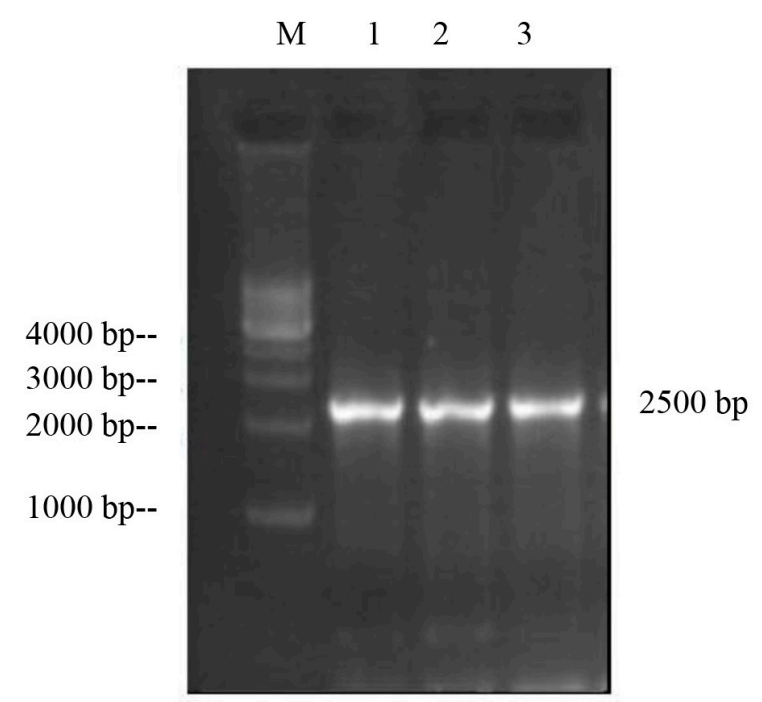

Figure 1. Agarose gel (1\%) electrophoresis of PCR products. Lane $M=$ DNA molecular weight marker; lanes 1-3 $=$ goose L-FABP cDNA samples 1,2 and 3 .

\begin{tabular}{|c|c|c|c|c|c|c|c|c|c|c|c|c|c|c|c|c|c|}
\hline & & 10 & & & 20 & & & 30 & & & 40 & & & 50 & & & 60 \\
\hline 1 & ATGGCAI & TTCAGTC & GGAP & $\mathrm{ACC}$ & TGGC & CAG & GTC & TATC & GCTC & CAAG & GAGAAC & ACTAT & TGAAC & GAGI & $\operatorname{TTT}$ & CTGP & A.AA \\
\hline \multirow[t]{2}{*}{1} & $M \quad \mathrm{~A}$ & F $\quad S$ & G & $T$ & W & $Q$ & V & $\mathrm{Y}$ & A & $Q$ & E $\quad \mathbb{N}$ & $\begin{array}{l}N \quad Y \\
\end{array}$ & E & E & F & I & $\mathrm{K}$ \\
\hline & & 70 & & & 80 & & & 90 & & & 100 & & & 10 & & & 120 \\
\hline 61 & GCTCTIC & GCACIGI & $\mathrm{CCAC}$ & GAAC & GAAC & CTT & ATC & AAAC & GICC & GCTP & AGAGA & ATATT & TAAGC & $\operatorname{CCTS}$ & GIT & GITS & GAA \\
\hline \multirow[t]{2}{*}{21} & A I & A L & $\mathrm{s}$ & E & E & I & I & $\mathrm{K}$ & $\mathrm{v}$ & A & R D & D I & $\mathrm{K}$ & P & V & $\mathrm{v}$ & $\mathrm{E}$ \\
\hline & & 130 & & & 40 & & & 150 & & & 160 & & & 70 & & & 180 \\
\hline 121 & ATACAGC & CAAAAAG & $\mathrm{GGAC}$ & GACC & GACT & ITT & GTG & GTGP & $\mathrm{ACAT}$ & $\mathrm{TCAA}$ & AAAAC & $\mathrm{CACCC}$ & CAAGC & CAAT & TCTC & GTAZ & $\mathrm{ACT}$ \\
\hline \multirow[t]{2}{*}{41} & I $Q$ & Q $K$ & G & D & D & F & V & v & $\mathrm{T}$ & s & K I & I $\mathrm{P}$ & $\mathrm{K}$ & $Q$ & $s$ & V & I \\
\hline & & 190 & & & 00 & & & 210 & & & 220 & & & 30 & & & 240 \\
\hline 181 & AACTCAI & ITTACAC & ETTE & GGA & AAAC & GAAC & GCT & GATP & ATTA & $\mathrm{ACTA}$ & ACTAT & TGGACl & CGGCA & AAAA & AAGC & CTAZ & AAG \\
\hline \multirow[t]{2}{*}{61} & $\mathrm{~N} S$ & F $\quad$ I & L & G & $\mathrm{K}$ & E & A & D & I & T & T $M$ & $M D$ & G & $\mathrm{K}$ & $\mathrm{K}$ & I & $\mathrm{K}$ \\
\hline & & 250 & & & 60 & & & 270 & & & 280 & & & 90 & & & 300 \\
\hline 241 & TGIACT & GTGAACO & ETAC & GTAZ & AATC & GGG: & AAG & $\operatorname{ctT}$ & GIGI & $T G C A$ & AAATCZ & CAGAT & & ITCI & $\mathrm{TCT}$ & CATS & GAG \\
\hline \multirow[t]{2}{*}{81} & C $\mathrm{T}$ & $\mathrm{V} N$ & L & $\mathrm{v}$ & $\mathrm{N}$ & G & $\mathrm{K}$ & L & $\mathrm{v}$ & C & K S & $S \quad D$ & $\mathrm{~K}$ & F & $\mathrm{s}$ & $\mathrm{H}$ & $\mathrm{E}$ \\
\hline & & 310 & & & 20 & & & 330 & & & 340 & & & 50 & & & 360 \\
\hline 301 & CAAGAAC & GTTAAAG & GGAP & AATE & GAAR & ATG & GTG & GAGP & ACTA & ATAA & ACTTT: & ITGGTC & IGGAG & GTAP & $\mathrm{ACGC}$ & CTTE & GTC \\
\hline \multirow[t]{2}{*}{101} & $Q E$ & $\mathrm{~V} \quad \mathrm{~K}$ & G & $\mathrm{N}$ & E & $M$ & $\mathrm{~V}$ & E & T & I & I $\quad \mathrm{E}$ & $G$ & G & $\mathrm{V}$ & T & I & $\mathrm{V}$ \\
\hline & & 370 & & & 80 & & & & & & & & & & & & \\
\hline 361 & AGAAGAP & AGCAAGA & $\mathrm{GGAC}$ & GTTI & TAA & & & & & & & & & & & & \\
\hline 121 & $\mathrm{R} \quad \mathrm{R}$ & $S \mathrm{~K}$ & $\mathrm{R}$ & V & * & & & & & & & & & & & & \\
\hline
\end{tabular}

Figure 2. Coding sequences and amino acid sequences of the goose $L-F A B P$ gene. 


\section{Alignment and phylogenetic analysis of the goose $L$-FABP gene}

The amino acid sequence alignment based on the GenBank database using BLAST revealed that the sequence of the goose $L-F A B P$ gene was consistent with those of $L-F A B P$ genes in other organisms, with the highest identity (98\%) to Anas platyrhynchos (GenBank ID: AAL32464.1), 92\% identity to Gallus gallus (NP 989965.1), 83\% identity to Zebra finch (XP_002196447.1), 71\% identity to Zebra fish (XP_002196447.1), and 69\% identity to Xenopus laevis (XP_002938785.1). These relationships are reflected in the phylogenetic tree (Figure 3).

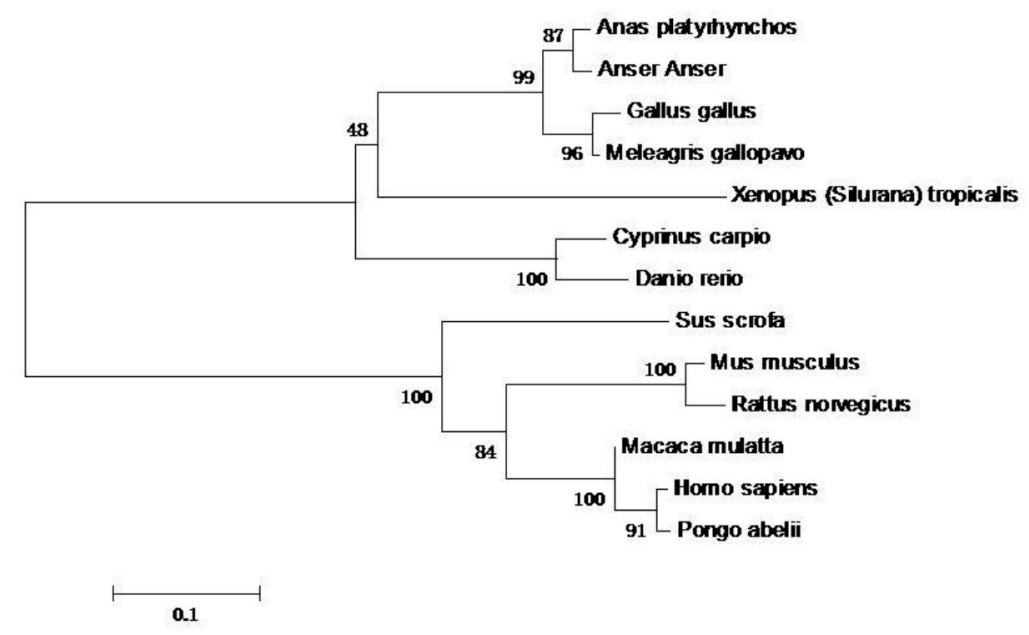

Figure 3. Phylogenetic tree of the goose $L-F A B P$ gene.

\section{Molecular characterization of goose L-FABP}

The molecular mass of goose L-FABP was predicted to be $14,105.2 \mathrm{Da}$, with a theoretical isoelectric point of 8.52 and molecular formula of $\mathrm{C}_{624} \mathrm{H}_{1015} \mathrm{~N}_{167} \mathrm{O}_{193} \mathrm{~S}_{5}$. Lysine and valine were the most abundant amino acids $(11.9 \%)$ and the lipid coefficient was found to be 82.62 . The overall hydrophobicity was -0.347 , indicating that the protein is strongly hydrophilic. Goose L-FABP hydrophobicity/hydrophilicity cluster analysis performed using ProtScale showed that goose L-FABP hydrophobicity ranged from -2.311-1.922, and thus goose L-FABP should be a water-soluble protein according to the results of the score region. The tertiary structure deduced using the Swiss-Model workspace software showing that goose L-FABP has a $\beta$-barrel-type structure composed of 10 anti-parallel $\beta$-chains and 2 short $\alpha$-helices at the N-terminus, which was identical to the prediction for Gallus gallus L-FABP (Schwede et al., 2003; Arnold et al., 2006; Wang et al., 2011).

\section{Expression analysis of the goose $L-F A B P$ gene}

The expression levels of goose $L-F A B P$ mRNA were highest in the liver (Figure 4). Expression levels of goose $L$-FABP mRNA in the liver of the overfeeding group was 4-fold higher than that of the control group $(\mathrm{P}<0.01$; Figure 5). 


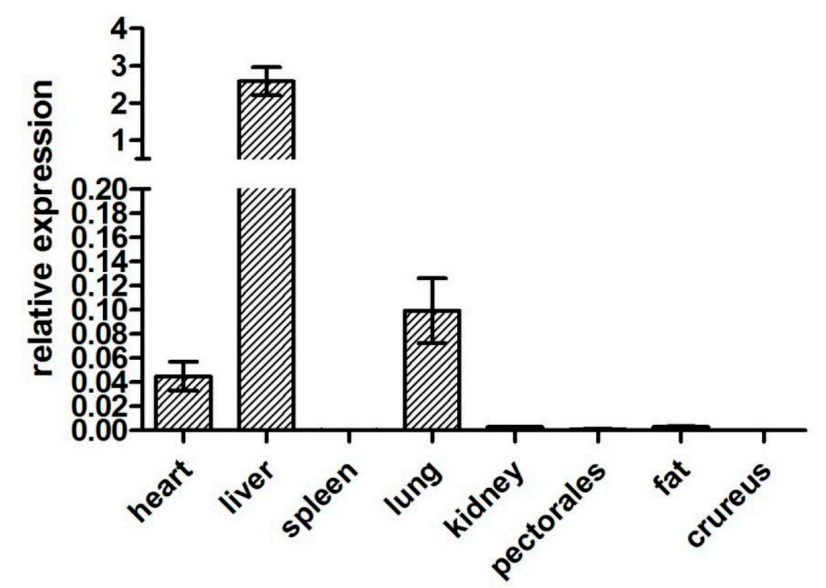

Figure 4. Relative mRNA expression $\left(2^{-\Delta \mathrm{Ct}}\right)$ levels of the goose $L-F A B P$ gene in different tissues obtained after normalization to $G A P D H$ gene.

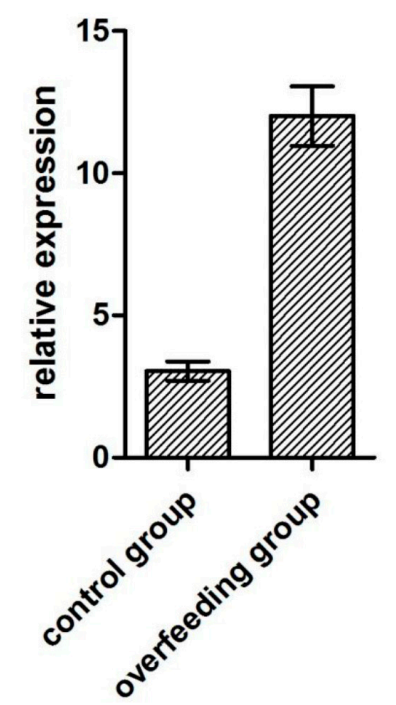

Figure 5. Hepatic mRNA expression levels of the $L-F A B P$ gene in the overfeeding group and the control group obtained after normalization to GAPDH gene.

\section{Polymorphisms analysis of the goose $L-F A B P$ gene}

Only 1 point mutation from $\mathrm{T}$ to $\mathrm{G}$ was identified at $774 \mathrm{bp}$ in intron 1 of the goose L-FABP sequence. Population genetic analysis revealed that the genotype frequencies of TT, TG, and GG were $0.4390,0.4512$, and 0.1098 , respectively. The allele frequencies of $\mathrm{T}$ and $\mathrm{G}$ were 0.6646 and 0.3354 , respectively. The chi-square test indicated that the Landes goose population with the polymorphic site was in Hardy-Weinberg equilibrium, heterozygosity was 0.4458 , the polymorphism information content was 0.3464 , and the population was moderately polymorphic $(0.25<$ polymorphism information content $<0.50)$ (Table 2$)$. 
Statistical analysis found no significant difference between TT, TG and GG genotypes; however, GG genotype geese have both a higher ratio of liver weight versus body weight and a better liver weight, which is 95 and $105 \mathrm{~g}$ bigger than that of TT and TG genotype geese, respectively (Table 2).

$\begin{aligned} & \text { Table 2. Population genetic analysis of the } L-F A B P \\
& \text { weight versus body weight of } 3 \text { genotypes. }\end{aligned}$
\begin{tabular}{lcccc}
\hline Genotypes or alleles & Practical observation number & Frequency of genotypes or alleles & Liver weight & Ratio of liver to body weight \\
\hline TT & 36 & 0.4390 & $873.61 \pm 164.08$ & $13.88 \pm 1.97$ \\
TG & 37 & 0.4512 & $863.38 \pm 168.35$ & $13.40 \pm 2.07$ \\
GG & 9 & 0.1098 & $968.89 \pm 184.56$ & $14.79 \pm 2.48$ \\
T & & 0.6646 & & \\
G & & 0.3354 & & \\
\hline
\end{tabular}

\section{DISCUSSION}

\section{Cloning and sequence analysis of the goose $L-F A B P$ gene}

In this study, we first obtained the full-length $L-F A B P$ gene from Landes geese. The 2490-bp sequences of goose contained 4 exons and 3 introns, encoding a peptide of 126 amino acids. The $L-F A B P$ gene was considered to be a conserved gene because of its high homology in different species. Phylogenetic analysis showed that goose $L-F A B P$ was first clustered with Anas platyrhynchos (GenBank ID: AAL32464.1), followed by other species. The tertiary structure of goose L-FABP was found to be identical to that predicted for Gallus gallus L-FABP.

\section{Expression analysis of goose L-FABP}

As expected, the expression levels of the L-FABP gene were highest in liver tissue, which is consistent with previous results for Anas platyrhynchos (He et al., 2013). The expression levels of the $L-F A B P$ gene in the liver after overfeeding were significantly higher. This gene is closely related to the transcription of regulatory genes and the synthesis of triglycerides, and likely plays an important role in the formation of fatty liver in overfeeding geese. The results of our investigation in Landes geese were consistent with those of previous studies. Wang et al. (2005) successfully transfected and cloned a Chang liver cell line that expressed the $L-F A B P$ gene; they demonstrated that L-FABP plays a significant role in oxidative stress.

$\mathrm{Xu}$ (2008) showed that the expression levels of the Landes goose $L-F A B P$ gene in the liver increased after overfeeding with a high-carbohydrate diet. The results also suggested that overfeeding had a positive effect on the formation and metabolism of fatty acids and the transportation of fatty acids in goose hepatocellular degeneration. The $L-F A B P$ gene participates in the formation and metabolism of fatty acids in several ways. It has been shown that the $L$ FABP gene transfers LCFAs into the nucleus, suggesting a model wherein L-FABP functions in nuclear receptor regulation by binding LCFAs to alter L-FABP conformation, traffics into the nucleus to bind with peroxisome proliferator-activated receptor- $\alpha$ (Lawrence et al., 2000; Huang et al., 2004; McIntosh et al., 2009). 


\section{Polymorphisms analysis and its association with fatty liver traits}

The intron was found to be an important element of the genome. Although it does not code for amino acids, it has a critical effect on the function, expression, and regulation of genes, maintaining specific chromosome structures (Jacquier, 1996; Kim et al., 1999; Klett and Bonner, 1999). In addition, previous study also found a novel single nucleotide polymorphism in exon 3 of the $L-F A B P$ gene in duck, which was associated with the contents of C16:0, C18:3, and total intramuscular fat in pectoral muscle (He et al., 2012).

As a response to the performance of the heterozygosity and the moderate polymorphic information content of Landes goose population in our study, polymorphism analysis of the Landes goose population indicated that the level of selection pressure of goose populations was low, resulting in a Hardy-Weinberg genetic equilibrium state in which the $L-F A B P$ gene is influenced by artificial selection, migration, and genetic drift, among other factors. There is no evidence of selection on this locus based on our results. However, different genotypes in Landes geese impact the weight of fatty liver and ratio of liver weight versus body weight. Geese with the GG genotype showed better performance for both liver weight and ratio of liver weight versus body weight compared to geese with the TT and TG genotypes, but the differences were not significant. The relationship between L-FABP and diet-induced nonalcoholic fatty liver disease and whether the L-FABP gene can be considered a molecular marker of fatty liver traits requires further investigations on large goose populations.

The molecular mechanism of the formation of goose fatty liver is complicated and requires further studies. Many researchers have hypothesized that adipose tissue formation, transportation, and disrupting the $\beta$-oxidation balance of fatty acids are primary causes of goose fatty liver formation (Fournier et al., 1997). Because fatty liver traits cannot be measured in living organism, the ability to select for efficiency of fatty liver traits is reduced. However, molecular marker-assisted selection with traditional breeding and modern molecular biotechnology can be used to speed up the breeding process of new strains with high fatty liver traits (Storch and McDermott, 2009).

\section{CONCLUSIONS}

The full-length $L-F A B P$ genes first obtained from Landes geese were 2490-bp sequences encoding a peptide of 126 amino acids, and the $L-F A B P$ gene had high homology in different species. The expression levels of the $L-F A B P$ gene in different tissues had a significant difference: it was the highest in liver tissue followed by kidney and fat tissue. The expression levels of the $L-F A B P$ gene in liver of overfed geese had a significant increase that is 4 times higher than those of the control group. We also found one point mutation from $\mathrm{T}$ to $\mathrm{G}$ in the intron 1 of goose, which resulted in the generation of 3 genotypes (i.e., TT, TG, GG). Geese with the GG genotype have a better performance on the weight of fatty liver and ratio of liver weight versus body weight when compared with those with TT and TG genotypes, but there was no significant difference on the performance of the weight of fatty liver and ratio of liver weight versus body weight among the 3 genotypes.

\section{ACKNOWLEDGMENTS}

Research supported by the Technology Support Program of Jiangsu Province (Jiang- 
su, China; grant \#BE2011328), the Jiangsu Agriculture Science and Technology Innovation Fund (Jiangsu, China; grant \#CX(12)2033), the Major Basic Research Project of the Education Department of Jiangsu Province (Jiangsu, China; grant \#10KJA230056), and the National Natural Science Foundation of China (Beijing, China; grant \#31372298). The authors thank Ian Dunn (Roslin Institute, Roslin, Midlothian, UK) for critical reading of the manuscript.

\section{REFERENCES}

Arnold K, Bordoli LK and Schwede T (2006). The SWISS-MODEL Workspace: A web-based environment for protein structure homology modelling. Bioinformatics 22: 195-201.

Atshaves BP, Martin GG, Hostetler AH, McIntosh AL, et al. (2010). Liver fatty acid-binding protein and obesity. J. Nutr. Biochem. 21: 1015-1032.

Chen AP, Tang YC, Davis V, Hsu FF, et al. (2013). Liver fatty acid binding protein (L-FABP) modulates murine stellate cell activation and diet-induced nonalcoholic fatty liver disease. Hepatology 5: 2202-2212.

Dharmarajan S, Newberry EP, Montenegro G, Nalbantoglu I, et al. (2013). Liver fatty acid-binding protein modifies intestinal fatty acid composition and adenoma formation in $\mathrm{Apc}^{\mathrm{Min} /}$ mice. Cancer Prev. Res. 6: 1026-1037.

Fournier E, Peresson R, Guy G and Hermier D (1997). Relationships between storage and secretion of hepatic lipids in two breeds of geese with different susceptibility to liver steatosis. Poult. Sci. 76: 599-607.

He J, Chen JC, Lu LZ, Tian Y, et al. (2012). A novel SNP of liver-type fatty acid-binding protein gene in duck and its associations with the intramuscular fat. Mol. Biol. Rep. 39: 1073-1077.

He J, Tian Y, Li JJ, Shen JD, et al. (2013). Expression pattern of L-FABP gene in different tissues and its regulation of fat metabolism-related genes in duck. Mol. Biol. Rep. 40: 189-195.

Huang H, Starodub O, McIntosh A, Atshaves BP, et al. (2004). Liver fatty acid binding protein colocalizes with peroxisome proliferator receptor alpha and enhances ligand distribution to nuclei of living cells. Biochemistry 43: 2484-2500.

Jacquier A (1996). Group II introns: elaborate ribozymes. Biochimie 78: 474-487.

Kim CH, Kim HS, Cubells JF and Kim KS (1999). A previously undescribed intron and extensive 5' upstream sequence, but not Phox2a-mediated transactivation, are necessary for high level cell type-specific expression of the human norepinephrine transporter gene. J. Biol. Chem. 27: 507-518.

Klett CP and Bonner TI (1999). Identification and characterization of the rat M1 muscarinic receptor promoter. $J$. Neurochem. 72: 900-909.

Lawrence JW, Kroll DJ and Eacho PI (2000). Ligand dependent interaction of hepatic fatty acid binding protein with the nucleus. J. Lipid. Res. 41: 1390-1401.

Martin GG, Danneberg H, Kumar LS, Atshaves BP, et al. (2003). Decreased liver fatty acid binding capacity and altered liver lipid distribution in mice lacking the liver fatty acid-binding protein gene. J. Biol. Chem. 278: 21429-21438.

McIntosh AL, Atshaves BP, Hostetler HA, Huang H, et al. (2009). Liver type fatty acid binding protein (L-FABP) gene ablation reduces nuclear ligand distribution and peroxisome proliferator activated receptor-alpha activity in cultured primary hepatocytes. Arch. Biochem. Biophy. 485: 160-173.

Newberry EP, Xie Y, Kennedy S, Han XL, et al. (2003). Decreased hepatic triglyceride accumulation and altered fatty acid uptake in mice with deletion of the liver fatty acid-binding protein gene. J. Biol. Chem. 278: 51664-51672.

Petrescu AD, Huang H, Martin GG, McIntosh AL, et al. (2013). Impact of L-FABP and glucose on polyunsaturated fatty acid induction of PPAR $\alpha$-regulated $\beta$-oxidative enzymes. Am. J. Physiol. 2: G241-G256.

Relija B, Szermutzky M, Henrich D, Maier M, et al. (2010). Intestinal-FABP and liver-FABP: novel markers for severe abdominal injury. Acad. Emerg. Med. 6: 729-735.

Richieri GV, Ogata RT and Kleinfeld AM (1996). Thermodynamic and kinetic properties of fatty acid interactions with rat liver fatty acid-binding protein. J. Biol. Chem. 271: 31068-31074.

Schwede T, Kopp J, Guex N and Peitsch MC (2003). SWISS-MODEL: an automated protein homology-modeling server. Nucleic Acids Res. 31: 3381-3385.

Seneshaw M, Klass D, Preiss E, Adler G, et al. (2005). Impaired hepatobiliary lipid metabolism in liver fatty acid binding protein 1 (FABP1) knockout mice. Z. Gastroenterol. 43: 2-40.

Storch J and McDermott L (2009). Structural and functional analysis of fatty acid-binding proteins. J. Lipid Res. 50: S126-31.

Wang GQ, Gong YW, Anderson J, Sun DF, et al. (2005). Antioxidative function of L-FABP in L-FABP stably transfected Chang liver cells. Hepatology 42: 871-979.

Wang Q, Li H, Li N, Leng L, et al. (2006). Tissue expression and association with fatness traits of liver fatty acid-binding 
protein gene in chicken. Poult. Sci. 85: 1890-1895.

Wang QG, Zhang QQ and Wang LH (2011). Research progress of chicken liver-type fatty acid binding protein. Heilongjiang. Anim. Husbandry Vet. Med. 12: 33-35.

Xu GQ (2008). Detection and Analysis of Differential Expression Genes of Fatty Liver in Landes Geese. Master`s thesis, College of Animal Science and Technology, Yang Zhou University, Yang Zhou.

Zhang R, Zhu LH, Zhang YH, Shao D, et al. (2013). cDNA cloning and the response to overfeeding in the expression of stearoyl-CoA desaturase 1 gene in Landes goose. Gene 512: 464-469.

Zhou CW, Pan F, Li QJ, Cui JH, et al. (2010). Relationships between L-FABP and non-alcoholic fatty liver disease and insulin resistance. J. Clin. Med. Practice 14: 92-94. 